\title{
流れおよび海底地形による波浪の変形計算法 \\ NUMERICAL MODELS FOR WAVE TRANSFORMATION DUE TO CURRENT-DEPTH REFRACTION
}

\author{
山口正隆*・畑田佳男**・日野幹雄***・細野浩司*** \\ By Masataka YAMAGUCHI, Yoshio HATADA, Mikio HINO and Kohji HOSONO
}

\begin{abstract}
This paper presents numerical models for wave transformation due to current-depth refraction in cases of both regular and irregular waves. The models are to solve the equations for wave number components and the conservation equation of wave action or wave action spectral density by the combination of the method of characteristics and an interpolation formula. Numerical solution agrees well with the theory in cases where a one-dimensional current exists on a uniform depth or a uniformly sloping bottom. It is also found that the wave height of irregular waves is not amplified by opposing currents as well as following currents and that the model renders a slight overestimation of wave height distribution in the case of opposing currents because of a directional leakage of energy.
\end{abstract}

\section{1. 緒言}

河口や砕波帯近傍さらに，海峡部や強い海流域におい てみられるような，波と流れが共存する平面的な場にお ける波浪の変形を究明することは科学的にも実用的にも きわめて重要な課題であり，従来より特に鉛直方向に一 様な流れを仮定した場合に対し種々の解析法が提案され てきた。 そして，これらの解析法のうち，幾何光学的近 似に基づく ray theory を用いる方法は，特別な条件の もとでは波向線が集中して焦線を形成し，理論が破たん するなどの欠陷を有しているものの, 取り扱いが最も簡 単で実用性に富むものと考えられる。

ところで，規則波を対象とした場合の流れおよび海底 地形変化による波浪変形問題に対して, 波速あるいは群 速度と流速のベクトル和の方向を有する特性曲線に沿う 数值積分から波向, 波長および波高変化を計算する方法 が Skovgaard and Jonsson ${ }^{1)}$ (1976), 岩垣・酒井・岡 ${ }^{21}$

(1977), および山田・渡辺・小森 ${ }^{3)}$ (1984) により提 案されている.これらの研究のうち, 岩垣ら (1977) は

\footnotetext{
* 正会員 工博 愛媛大学教授 工学部海洋工学科 （厈790 松山市文京町 3)

** 正会員 工修 愛媛大学助手 工学部海洋工学科 (同上)

*** 学生会員 愛媛大学大学院工学研究科 (同上)
}

波向と波高を求めるために, 2 種類の異なる特性曲線を 用いており，しかも波高計算は表示が複雑なエネルギー 平衡方程式に基づいているため, 計算結果の精度がやや 低下しているように思われる. Skovgaard ら (1976) は波向線の方程式から波向を，また山田ら（1984）は波 数成分に関する方程式から波長および波向を求めるとと もに，波高変化に関しては両者とも波向線間で wave action flux が保存されるという条件を用いている.し たがって, 両者のモデルでは, 波高を求めるために, い ずれも波向線間隔を算出する必要があるが, 現地海岸に おけるように，波向線が複雑に変化する場合には，その 推定が困難になる，そこで，本研究の前半部では，波数 成分に関する方程式と wave action の保存則が同一の特 性曲線をもつことに注目して，これらの方程式を特性曲 線法によって数值積分し, 一次平面補間を通じて最終的 に格子点上での波向, 波長および波高を算出する数值計 算法を提案する.

一方, 不規則波の場合の研究例は数少ないが, Wang and $\mathrm{Yang}^{4)}$ (1981), 酒井・小関・岩垣 ${ }^{5)}$ (1981) および Chen and $\mathrm{Wang}^{6)}$ (1983) により数值モデルが提案され ている. Wang ら (1981) およびChenら (1983) は, それぞれ規則波と流れが共存する場合に対する定常およ び非定常状態での波に関するエネルギー平衡方程式を彼 
らのモデルに準用することにより流れの効果を考慮して いるが, 彼らの研究の主目的は流れの効果を無視した場 合のモデルの現地海岸への適用性の検討にあり, 流れの 波浪変形に及ぼす影響は調べられていない。 また，酒井 ら（1981）は波のエネルギースペクトルの代わりに wave action 方向スペクトル密度を用いて, 不規則波の エネルギーの保存則を任意の流れおよび海底地形変化が 同時に存在する場合に拡張するとともに, 差分法を適用 した数値モデルと若干の計算例を示したが, 流れと海底 地形変化が同時に存在する場合の計算結果は与えられて いない.

さて, 流れおよび海底地形変化が存在する場合には, 伝播過程においてエネルギーの流出入がなければ，個々 の波向線に沿って wave action 波数スペクトル密度は保 存されることが, Willebrand ${ }^{7)}$ (1975), James, Dalrymple and Tayfun ${ }^{8)}$ (1977)，および LeBlond and Mysak ${ }^{9)}$ （1978）らにより明らかにされている. そして，この保 存則に基づいて Tayfun, Dalrymple and Yang ${ }^{10)}$ (1976) と James ら (1977) は, 平行等深線地形上に一次元流 れが存在するという単純な場合に対する解析解の挙動を 調べているし，またごく最近，Mathiesen ${ }^{11)}$ (1984) お よび Brink-Kjaer ${ }^{12)}$ （1984）は任意の流れ分布および海 底地形変化をもつ場合に適用可能な不規則波の変形計算 モデルを提案している. しかしながら，彼らの数値モデ ルは本質的に 1 地点での波浪変形を計算する方法である ので,計算対象全領域における波浪変形を算出するのは, 計算時間の面から非常に困難である. そこで, 本研究の 後半部では, 任意の流れおよび海底地形変化が存在する 場合を対象として, 特性曲線法の一種である piecewise ray method と高次平面補間式および方向に関する一次 補間式の併用により, 各格子点での方向スペクトルの時 間変化を計算できる不規則波浪の変形計算法を提案する とともに，一様水深地形や一様勾配をもつ平行等深線地 形上に一次元流れが存在するという単純な場合について 数値計算を行い, 解析解との比較から数値モデルの妥当 性を検討する。

\section{2. 規則波の波浪変形計算}

\section{（1）基礎方程式}

いま，単一進行波を考えれば，波数の非回転条件およ び波数の保存則はそれぞれ次式で与えられる.

$$
\begin{aligned}
& \frac{\partial k_{x}}{\partial y}=\frac{\partial k_{y}}{\partial x} \\
& \frac{\partial k_{x}}{\partial t}+\frac{\partial \sigma}{\partial x}=0, \frac{\partial k_{y}}{\partial t}+\frac{\partial \sigma}{\partial y}=0
\end{aligned}
$$

ここに, $k_{x}$ および $k_{y}$ は波数ベクトルの $x$ 方向および $y$ 方向成分であり, 波数 $k$ および波向 $\theta$ 之の関係は, $k_{x}=k \cos \theta, \quad k_{y}=k \sin \theta$

で表わされる.また $\sigma$ は固定座標系からみた角振動数 であり, 波数成分 $\left(k_{x}, k_{y}\right)$ をもつ波が流れ $(U, V)$ に乗っ て伝播している場合には次式で与えられる。

$$
\sigma=\sigma_{m}+k_{x} U+k_{y} V
$$

そして, 流れとともに動く座標系からみた波の角振動数

$\sigma_{m}$ は微小振幅波理論を仮定すれば,

$\sigma_{m}^{2}=g k \tanh k h$

で表わされる.ここに, $g$ : 重力の加速度および $h$ : 水 深，である.

さて, $\sigma_{m}=\sigma_{m}\left(k_{x}, k_{y}, h\right)$ という関数関係を考慮して 式（1)，（2）および（4)を用いれば，波数成分 $k_{x}$ および $k_{y}$ に対する方程式が次式のように導かれる.

$$
\begin{gathered}
\frac{\partial k_{x}}{\partial t}+\left(C_{g} \cos \theta+U\right) \frac{\partial k_{x}}{\partial x}+\left(C_{g} \sin \theta+V\right) \frac{\partial k_{x}}{\partial y} \\
=-\frac{g k^{2} \operatorname{sech}^{2} k h}{2 \sigma_{m}} \frac{\partial h}{\partial x}-k_{x} \frac{\partial U}{\partial x}-k_{y} \frac{\partial V}{\partial x} \\
\frac{\partial k_{y}}{\partial t}+\left(C_{g} \cos \theta+U\right) \frac{\partial k_{y}}{\partial x}+\left(C_{g} \sin \theta+V\right) \frac{\partial k_{y}}{\partial y} \\
=-\frac{g k^{2} \operatorname{sech}^{2} k h}{2 \sigma_{m}} \frac{\partial h}{\partial y}-k_{x} \frac{\partial U}{\partial y}-k_{y} \frac{\partial V}{\partial y}
\end{gathered}
$$

ここに, $C_{\boldsymbol{g}}$ は群速度であり, 波速を $C$ とすれば次式で 表わされる.

$$
C_{g}=\frac{1}{2}\left(1+\frac{2 k h}{\sinh 2 k h}\right) \sqrt{\frac{g}{k} \tanh k h}=n C
$$

次に，波と流れの共存場におけるエネルギー逸散を無 視した波に関するエネルギー平衡方程式に, 式（1) (4), 鉛直方向に積分した運動量方程式および微小振幅 波理論に基づく radiation stress の表示式を適用して変 形すれば，wave action $E / \sigma_{m}$ に関する保存則が導かれ る.これを式 $(6)$ と同様の形で表示すれば, 次式で与 えられる。

$$
\begin{aligned}
& \frac{\partial}{\partial t}\left(\frac{E}{\sigma_{m}}\right)+\left(C_{g} \cos \theta+U\right) \frac{\partial}{\partial x}\left(\frac{E}{\sigma_{m}}\right)+\left(C_{g} \sin \theta\right. \\
& +V) \frac{\partial}{\partial y}\left(\frac{E}{\sigma_{m}}\right)=-\left\{\frac{\partial}{\partial x}\left(C_{g} \cos \theta+U\right)\right. \\
& \left.+\frac{\partial}{\partial y}\left(C_{g} \sin \theta+V\right)\right\}\left(\frac{E}{\sigma_{m}}\right)
\end{aligned}
$$

ここに, $E\left(=1 / 8 \rho g H^{2}\right):$ 波のエネルギーおよび $H:$ 波 高,である. 以上により, 式 (6) および（８）を解けば, 波数, 波向および波高変化が算出される.

さて, 平行等深線地形に一次元流れ $(U(y), 0)$ が存在 する場合には, 現象は $x$ 方向に変化しないので, 式 (1) の右辺が 0 となり,

$k \cos \theta=k_{0} \cos \theta_{0}=$ const 
といういわゆる流れおよび海底地形変化が存在する場合 の Snell の法則が導かれる.ここに，suffix ‘。'は流れ の存在しない場所を意味する.したがって式（9）を変 形すれば, 任意地点の波向は,

$$
\frac{\cos \theta}{\cos \theta_{0}}=\left(1-\frac{U}{C_{0}} \cos \theta_{0}\right)^{-2} \frac{\tanh k h}{\tanh k_{0} h_{0}}
$$

で表わされるが, $\cos \theta$ は 1 以下であるから, 解が存在 する $U$ の上限が,

$$
\frac{U}{C_{0}} \leqq\left\{1-\left(\cos \theta_{0} \frac{\tanh k h}{\tanh k_{0} h_{0}}\right)^{1 / 2}\right\} / \cos \theta_{0}
$$

で与えられる2).一方，波高は式 (8) から，

$$
\frac{H}{H_{0}}=\left(\frac{\sin 2 \theta_{0}}{\sin 2 \theta}\right)^{1 / 2}\left(\frac{n}{n_{0}}\right)^{1 / 2}
$$

として与えられる。そして，式（10）および（12）の特 性は岩垣ら（1977）によって詳細に検討されている.

\section{（2）数値計算法}

式（6）および（8）はいずれも,

$$
\frac{d x}{d t}=C_{g} \cos \theta+U, \frac{d y}{d t}=C_{g} \sin \theta+V
$$

で与えられる特性曲線をもつので,その特性曲線上では, 式（6）および（8）の左辺は単に時間に関する常微分 項になる、ここに， $x$ および $y$ は特性曲線の位置を表 わす。そこで，具体的な計算手順は次のようである.

（i）計算対象領域を正方格子網（分割数 $M \times N$, 格子間隔 $\Delta s ）$ に分割し, 格子点上の水深 $h$ およ び流速（Uおよび $V$ ) を与えるとともに，それ らの勾配を計算する。

（ii）冲側境界での境界条件として与える周期 $T$, 水深 $h_{0}$, 波向 $\theta_{0}$, 流速 $\left(U_{0}=V_{0}=0\right)$ を用い, 式 (4) および（5）を Newton 法で解くことにより， $k_{0}$, $k_{x 0}$ および $k_{y 0}$ を計算するとともに, 波向線の出 発位置 $\left(x_{0}, y_{0}\right)$ を与える.

（iii）式（13）および（6）を三次の Runge-Kutta 法によって解き，波向線の位置と波向線上の波数 および波向を求める.この際，計算に必要な波向 線上の $h, \partial h / \partial x, \partial h / \partial y, \partial U / \partial x, \partial U / \partial y$, $\partial V / \partial x$ および $\partial V / \partial y$ などは, 一次平面補間式 により格子点上の值から内挿する．波向線の計算 は, (a) 波向線が計算対象領域から出る場合，(b) 波向線到達地点の水深が非常に小さくなる場合 $(h=5 \mathrm{~cm}),(\mathrm{c})$ 波向線が沖に向かう場合，に 終了し，次の波向線の計算に移る.

（iv）波向線の進行方向および $x$ 軸方向に一次補間 を行うことにより, 各格子点上の波向 $\theta$ を推定 する。

（V）各格子点の $T, h, \theta, U$ および $V$ を用い, 式（4）および（5）から Newton 法により $k$ および $C_{g}$ を算出するとともに，各格子点におけ
る $\theta$ と $C_{g}$ の勾配 $\partial \theta / \partial x, \partial \theta / \partial y, \partial C_{g} / \partial x$ お よび $\partial C_{g} / \partial y$ を中央差分により求める.

(vi） 式（13)，（6）および（8）を三次の RungeKutta 法により再度解く。その際式（8）に含ま れる波向線上の $\partial \theta / \partial x, \partial \theta / \partial y, \partial C_{g} / \partial x$ およ び $\partial C_{g} / \partial y$ は格子点での值から一次平面補間式 により内挿する.

（vii）（vi）之同様の操作により各格子点上の波向を 内挿する。

\section{（3）計算結果および考察}

本研究の数值計算モデルは，任意の流れ分布および海 底地形に対して適用可能であるが，ここでは，理論と計 算結果との比較に基づいて数値計算法の妥当性を検討す るという立場から, 理論解が存在する単純なケースに対 して計算を実施する，そのため，数値計算例として，岩 垣ら（1977）が用いた Fig. 1 に示す $500 \mathrm{~m} \times 500 \mathrm{~m}$ の領 域を考える，岩垣らと同様に，この領域を $26 \times 26$ に分 割し, 次式で示すような $U$ 成分のみからなる流速分布 を仮定する。

$$
\left.\begin{array}{ll}
U=0 & ; 0 \leqq y \leqq 80 \mathrm{~m} \\
U=0.01 \times(y-80) & ; 80 \mathrm{~m} \leqq y \leqq 500 \mathrm{~m}
\end{array}\right\}
$$

また，水深は一様水深の場合 $(h=30 \mathrm{~m})$ と一様勾配 $(i$ $=1 / 50, y=500 \mathrm{~m}$ で $h=0)$ を考え, 境界 $y=0$ で, 周 期 $T=5 \mathrm{~s}$, 波高 $H_{0}=1 \mathrm{~m}$, 波向 $\theta_{0}=60^{\circ}$ あるいは $120^{\circ}$ を

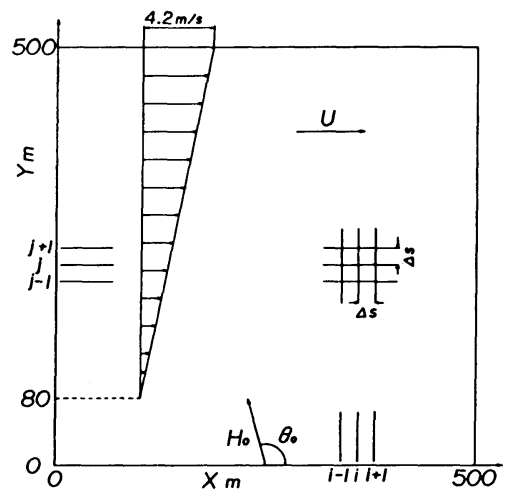

Fig. 1 Computation region and current distribution (after Iwagaki et al. (1977)).

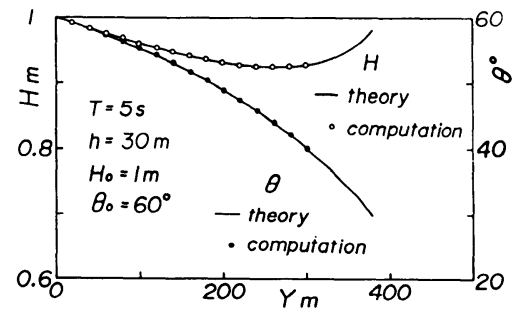

Fig. 2 Change of wave height in case of uniform depth (1). 


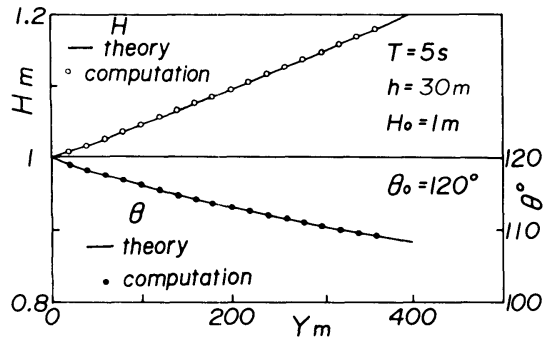

Fig. 3 Change of wave height in case of uniform depth (2).

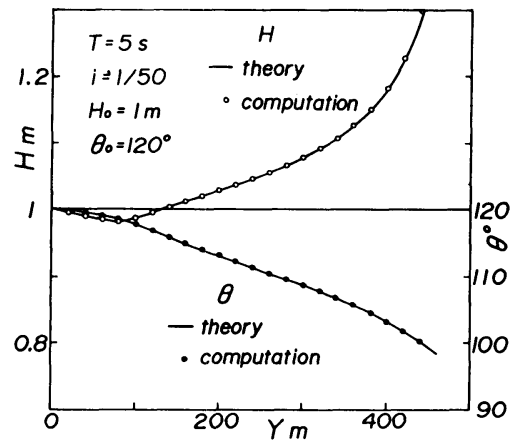

Fig. 4 Change of wave height in case of sloping beach.

与えた. Fig. 2 および Fig. 3 は一様水深の場合の計算結 果であり，図中の実線が式 (10) および（12）から求め た結果を，丸印が計算結果を示す。これらの眓によると， 岩垣ら（1977）の数値計算結果は理論曲線と若干の相違 を示していたのに比べて，本研究の計算結果はほぼ完全 に一致しており, 本研究の数值計算法の妥当性が確かめ られる．また，Fig. 4 は海底勾配 $i=1 / 50$ を有する平行 等深線地形に対する結果であり，この図においてもほほ 完全な一致が得られている。ただし, 波高急増部分の 1 点で波高に関してわずかな隔たりが存在するのは $\theta$ お よび $C_{g}$ の勾配の変化が大きいこの領域で， $\theta$ および $C_{g}$ の勾配を中央差分で求めたことによる誤差に起因するも のであり，より良好な対応関係を得るためには，格子間 隔を小さくとり， $\theta$ および $C_{g}$ の推定精度を向上させる 必要がある.

\section{3. 不規則波の波浪変形計算}

\section{（1）基礎方程式}

Willebrand（1975）によれば，流れおよび海底地形 変化がある場合の wave action 波数スペクトル密度 $w=E\left(k_{x}, k_{y}\right) / \sigma_{m}$ の保存則はエネルギー逸散が無視され る場合には次式で与えられる.

$$
\frac{\partial w}{\partial t}+\frac{d x}{d t} \frac{\partial w}{\partial x}+\frac{d y}{d t} \frac{\partial w}{\partial y}+\frac{d k_{x}}{d t} \frac{\partial w}{\partial k_{x}}+\frac{d k_{y}}{d t} \frac{\partial w}{\partial k_{y}}=0
$$

したがって，各波数成分あるいは周波数方向成分ごとに 式（13）および（6）で定義される波向線上で,

$w=$ const.

が成立し，これを周波数方向空間で表わせば,

$$
w(f, \theta)=\frac{\left(C_{g}+U \cos \theta+V \sin \theta\right)}{2 \pi k} \frac{E(f, \theta)}{\sigma_{m}}=\text { const } .
$$

となる.ここに, $w(f, \theta)$ : wave action 方向スペクトル 密度および $E(f, \theta)$ : 方向スペクトル，である. 式 (17) において解が存在するためには，

$C_{g}+U \cos \theta+V \sin \theta>0$

が成立しなければならない,つまり, 式（18）は波が流 れに逆らって伝播できる範囲を表わす。

さて, 規則波の場合と同様に, 平行等深線地形に一次 元流れ $(U(y), 0)$ が存在する場合には, 現象は $x$ 方向 に変化しないので, Snell の法則, 式（9）が成立する. 式（9）は波向を求めるための式であるが，波数 $k$ は 式 (4) および ( 5 )を解くことにより算出される.一方, 任意地点の方向スペクトルは，式 (17) から,

$$
E(f, \theta)=\left(\frac{k}{k_{0}}\right)\left(\frac{C_{g 0}}{C_{g}+U \cos \theta}\right)\left(\frac{\sigma_{m}}{\sigma}\right) E_{0}\left(f, \theta_{0}\right)
$$

により与えられる. そして, これに若干の変形を施せば 次式になる.

$$
\begin{aligned}
E(f, \theta)= & \left(\frac{k}{k_{0}}\right)^{2}\left\{\frac{n_{0}\left(1-U \cos \theta_{0} / C_{0}\right)}{n+(1-n)\left(U \cos \theta_{0} / C_{0}\right)}\right\} \\
& \cdot E_{0}\left(f, \theta_{0}\right) \ldots \ldots \ldots \ldots \ldots \ldots \ldots \ldots \ldots \ldots \ldots \ldots \ldots \ldots \ldots \ldots \ldots \ldots
\end{aligned}
$$

式（20）はTayfunら（1976）によって導かれた平行等 深線地形に一次元流れが存在する場合の方向スペクトル 変化を表わす表示式である.

\section{（2）数值計算法}

前述のように, wave action 波数スペクトル密度は波 向線に沿って保存されるので, 各周波数方向成分ごとに 計算対象全領域を特性曲線でおおえば，原理的に解が求 められる. しかしながら，この方法により領域全体での 解を求めるためには膨大な計算機の使用時間と記憶容量 を必要とするうえに，各格子点での方向スペクトル值を 直接算出することができない. そこで，この問題点を解 決するため，特性曲線法の一種である piecewise ray method と高次平面補間式および方向に関する一次補間 式を併用する方法を採用する.すなわち，Fig. 5 に示す ように, 格子内点 $(x, y)$ より $n$ 時点に波向 $\theta$ で出発し た wave action 方向スペクトル密度 $w(f, \theta)$ が $n+1$ 時 点に初期データとして与えられた波向 $\theta_{m}$ をもって格子 点に到達すると考える. その際, wave action 方向スぺ クトル密度の通過経路, 出発位置およびそこでの波向は, 式（13）および（6）から, 波数および波向を初期条件 


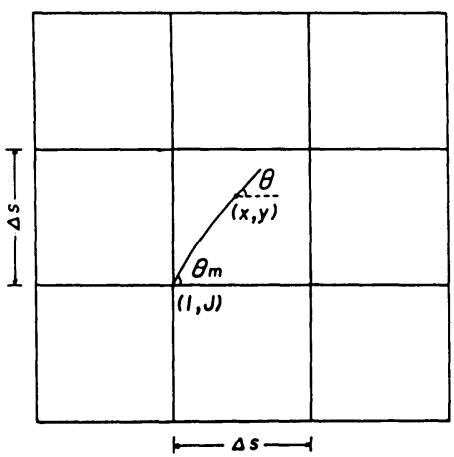

Fig. 5 Computation of direction of propagation.

として与えた逆屈折計算を行うことによりあらかじめ計 算される。しかし, 流れが存在する場合の逆屈折計算は 水深変化のみが存在する場合のそれと異なり,たとえば, 屈折計算では順流状態であるものが，逆屈折計算では逆 流状態になるというように非可逆的であるので，波向を 単に逆（波向に $\pi$ を加える）にするだけでなく，流向 も逆転させる必要がある。，そして，計算に必要な格子内 点での諸量 $(h, U, V, \partial h / \partial x, \partial h / \partial y, \partial U / \partial x, \partial U / \partial y$, $\partial V / \partial x, \partial V / \partial y$ および $w(f, \theta))$ は, 一次平面補間式を 適用して格子点から推定するが, 特に, wave action 方 向スペクトル密度に対しては, 数值分散を小さくするた め, 16 点三次 Lagrange 補間式を用い, 三次式が適用 できない境界および境界近傍では，一次平面補間式を適 用する．また，wave action 方向スペクトル密度は 0 ま たは正の值であるが，16点三次補間式を適用すると， 負の值をとる場合もあるので, その場合には再度一次平 面補間式を適用することによりこの問題点を解決してい る.

ところで, 前述のように, 格子内点での波向は屈折に より格子点での波向と異なるので, 格子点での wave action 方向スペクトル密度から格子内点でのそれを直 接内挿することができない，そこで，まず格子内点での 波向 $\theta$ をはさみ込む 2 つの波向 $\theta_{k}$ および $\theta_{k+1}$ に対して 格子内点での wave action 方向スペクトル密度を内挿し たのちこれらを方向に関して次式のように一次補間す ることにより算出した格子内点での波向 $\theta$ に対する wave action 方向スペクトル密度 $w(f, \theta)$ を格子点での 波向 $\theta_{m}$ に対する wave action 方向スペクトル密度 $w(f$, $\left.\theta_{m}\right)$ に等しいとし, さらに方向スペクトル $E\left(f, \theta_{m}\right)$ に変 換した。すなわち，

$$
\begin{aligned}
& w\left(f, \theta_{m}\right)=w(f, \theta)=w\left(f, \theta_{\kappa}\right)+\left\{w\left(f, \theta_{\kappa+1}\right)\right. \\
& -w\left(f, \theta_{\kappa}\right) \cdot\left(\frac{\theta-\theta_{k}}{\theta_{k+1}-\theta_{\kappa}}\right)
\end{aligned}
$$

計算に用いる初期条件および境界条件として，任意の 流れおよび海底地形変化を有する場合には, 流入境界に
あたる沖側の境界で適当な既知の方向スペクトルを与 え, 岸側では, 流出境界 (wave action 方向スペクトル 密度の完全吸収)，また側方境界では，流出入境界（た だし，伝播方向に対して流入境界にあたる場合には， wave action 方向スペクトル密度は0）としたが，一方 向に関して現象が変化しない単純な場合には，側方境界 条件として周期性境界条件を採用した。

具体的な計算手順は次のように記述される.

（i）計算対象領域を正方格子網に分割し，格子点上 の水深 $h$ および流速 $(U$ および $V)$ を与える.

（ii）沖側境界で有義波高 $H_{(1 / 3)}$, 有義波周期 $T_{(1 / 3)}$, 主方向 $\theta_{p}$, 周波数 $f$ および方向 $\theta$ を与え, 適当 な方向スペクトルモデルから沖側境界 $(y=0)$ での入力方向スペクトル $E_{0}(f, \theta)$ および入力 wave action 方向スペクトル密度 $w_{0}(f, \theta)$ を計算 する.

（iii）各格子点で, 各周波数および波向ごとに逆屈折 計算を三次の Runge-Kutta 法により行い，1 夕 イムステップ $\Delta t$ 後の格子内点における波向線の 位置および波向を計算し, 記憶させる.この場合, 初期值に相当する格子点での波数成分 $k_{x}$ および $k_{y}$ は与えられた周波数, 方向, 水深および流速 のもとに, 式 (4) および（5）を Newton 法で 解くことにより求められる. また, 計算に必要な 格子内点での諸量は一次平面補間式により内挿す る.

（iv）各格子点に方向 $\theta_{m}$ をもって到達する格子内点 での波向 $\theta$ をはさみ込む 2 つの波向, $\theta_{k}$ および $\theta_{\boldsymbol{N}+1}$ に対応する wave action 方向スペクトル密 度, $w\left(f, \theta_{k}\right)$ および $w\left(f, \theta_{k+1}\right)$ をそれぞれ三次 Lagrange 補間式の適用により推定する.

（v）（iv）の内挿結果に式（21）を適用して, 格子 点での波向 $\theta_{m}$ に対応する wave action 方向スペ クトル密度 $w\left(f, \theta_{m}\right)$ を全格子点の全周波数およ び全方向について推定するとともに，方向スペク トル $E\left(f, \theta_{m}\right)$ を計算する.

（vi）（iv）および（V）の計算を方向スペクトルの 計算結果が各タイムステップごとにほとんど変化 しなくなるまで繰り返して定常解を得たのち，そ の数值積分から周波数スペクトル $E(f)$, 有義波 高 $H_{(1 / 3)}$, 有義波周期 $T_{(1 / 3)}\left(=1.22 T_{z}\right)$ および平均 波向 $\bar{\theta}$ を算出する．ここに，T $T_{z}$ はスペクトルの 零次積率と二次積率の比の平方根で定義される平 均周期である.

\section{（3）数值計算結果および考察}

計算領域は, Fig. 1 と同様に一様水深 $(h=50 \mathrm{~m})$ あ るいは海底勾配 $i=1 / 50$ (最大水深 $40 \mathrm{~m}$, 最小水深 $4 \mathrm{~m}$ ) 
をもつ水域を $\Delta s=200 \mathrm{~m}$ で $10 \times 10$ に等分割したもので あり，その水域に， $\partial U / \partial y=-1 / 1000$ をもつ一次元流 れ $U(y)(U=0 \sim-1.4 \mathrm{~m} / \mathrm{s})$ が存在するものとしている. そして, 入力方向スペクトルとして,$j=1 \quad(i=1 \sim 10)$ において次式で表わされる光易型方向スペクトルをもつ 不規則波浪卓を与える.

$$
\begin{aligned}
E_{0}(f, \theta) & =E_{0}(f) \cdot D_{0}(f, \theta) \\
E_{0}(f)= & 0.257 H_{(1 / 3) 0}^{2} T_{(1 / 30)}\left(T_{(1 / 300} f\right)^{-5} \\
& \cdot \exp \left\{-1.03\left(T_{(1 / 300} f\right)^{-4}\right\} \\
D_{0}(f, \theta) & =\frac{1}{\pi} 2^{2 s-1} \frac{\Gamma^{2}(s+1)}{\Gamma(2 s+1)} \cos ^{2 s} \frac{\left(\theta-\theta_{p}\right)}{2}
\end{aligned}
$$

ここに, $\theta_{p}$ : 主波向, $D(f, \theta)$ : 方向分布関数および $\Gamma$ : Gamma 関数，である．数値計算にあたっては，標準 的条件として $H_{(1 / 3) 0}=3 \mathrm{~m}, \quad T_{(1 / 3) 0}=7 \mathrm{~s}, \quad S_{\max }=10$, $\theta_{p}=60^{\circ}$ あるいは $120^{\circ}$ を与えて，入力方向スペクトル $E_{0}(f, \theta)$ を計算するとともに, $\theta=0^{\circ}$ および $180^{\circ}$ ではそ れぞれ $E_{0}(f, \theta)=0$ とした。 また，計算に用いた周波数 は $f=0.09 \sim 0.71 \mathrm{~Hz}$ 間の 20 個, 方向成分は $\theta=0^{\circ} \sim$ $180^{\circ}$ 間の 73 個 $\left(\Delta \theta=2.5^{\circ}\right)$ であり，時間間隔 $\Delta t=15$ $\mathrm{s}$ の条件のもとに 240－300回の繰り返し計算で定常解 を得た。

ところで, 本研究の計算ケースの場合, $0^{\circ}<\theta_{0}<90^{\circ}$ の範囲は与えた流速に対し逆流状態になる。そして，沖 側境界での波向 $\theta_{0}=0^{\circ}$ に対し計算対象地点で計算され る波向は $\theta_{\mathrm{cl}}(>0)$ となるので, 計算対象地点では限界波 向 $\theta_{c 1}$ より小さい方向をもつ方向スペクトルは存在しな い.しかも，たとえば， $\theta_{0}<45^{\circ}$ というように $\theta_{0}$ の值が 小さい波浪成分の対象地点での波向は $\theta=\theta_{\mathrm{c} 1}$ 付近に集 中する結果, $\theta=\theta_{c 1}$ 付近での方向スペクトルの変化率 がきわめて大きくなる.一方，一般に数值計算によれば, $\theta=\theta_{c 1}$ 付近におけるような関数値の急激な変化を再現 することは非常に難しく，数値解は平滑化されざるを得 ないので, $\theta=\theta_{c 1}$ 付近で方向に関するエネルギーのも れが生ずる.そして, 現在の場合, 周波数が増加するほど, $\theta=\theta_{c 1}$ 付近における方向スペクトルの変化率が大きい ので，方向に関するエネルギーのもれも増大する．しか しながら, 方向分割数を本研究で採用した 73 個程度に とれば，少なくとも波浪エネルギーの大部分を占める低 周波側においては，計算結果は理論結果をかなりよく再 現するので， $\theta=\theta_{c 1}$ 付近におけるエネルギーのもれは 実用上それほど問題にならないと考えられる。

Fig. 6 は一样水深 $h=50 \mathrm{~m}$ の水域に $\theta_{p}=60^{\circ}$ あるいは $\theta_{p}=120^{\circ}$ の不規則波が入射した場合（case 1 および case 2）の有義波高の空間分布および計算で与えた流速 分布を示したものであり, 図中の実線は理論值を, 点線 は計算結果を，さらに一点鎖線は有義波に相当する波高

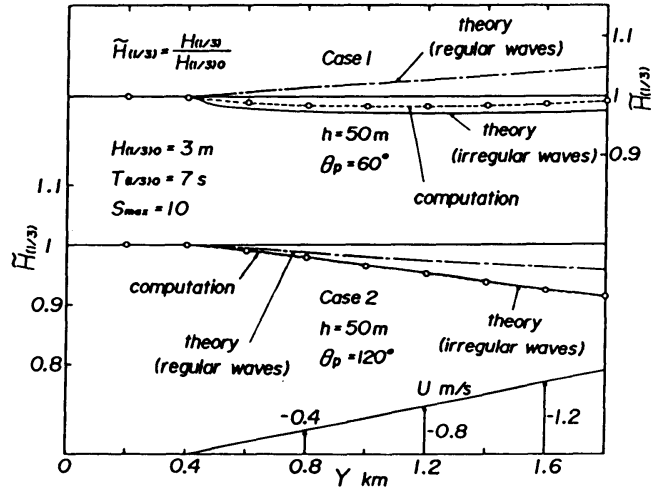

Fig. 6 Change of significant wave height in case of uniform depth (case 1 and case 2).

および周期を与えて計算した規則波の場合の結果（この 場合，理論と計算結果はほぼ完全に一致する）を表わす。 まず case 1 は逆流成分が卓越する場合に相当し, 事実, 規則波の場合の計算結果は流速の増大とともに増大して いる。しかしながら，不規則波の場合には理論および計 算結果のいずれもが，流速の増加とともに一度減少した のち，非常に緩やかな増加傾向に移っている．これは， 逆流状態に相当する $0^{\circ}<\theta_{0}<90^{\circ}$ の範囲の方向スペクト ルは確かに流速の増大とともに増加するが，前述のよう に屈折に伴い $\theta_{0}<90^{\circ}$ では方向スペクトルが存在する波 向の範囲が狭くなるとともに, $90^{\circ}<\theta_{0}<180^{\circ}$ の順流状 態では方向スペクトルが減少する結果, 方向スペクトル 値の積分量である波高が少なくとも沖側領域で与えた波 高より小さくなると考えられる．なお，理論曲線と計算 結果の隔たりは前述した方向に関するエネルギーのもれ によるものである.

ついで, case 2 ではエネルギー減少を示す順流成分が 卓越し，しかもエネルギー増加を示す逆流成分は順流成 分に比べて小さいので，波高は流速の増大とともに規則

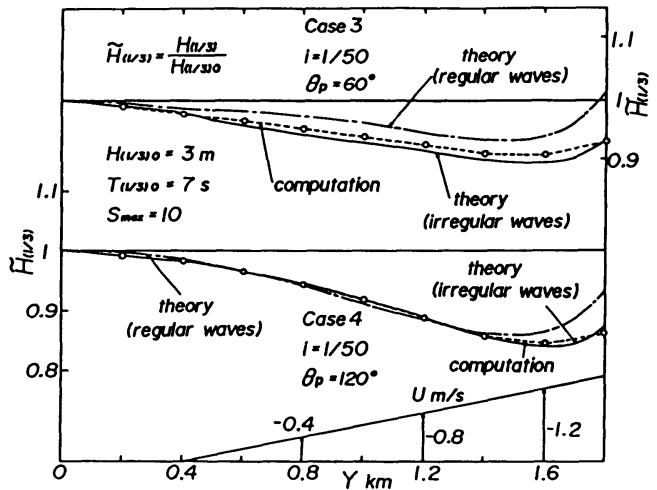

Fig. 7 Change of significant wave height in case of sloping beach (case 3 and case 4 ). 

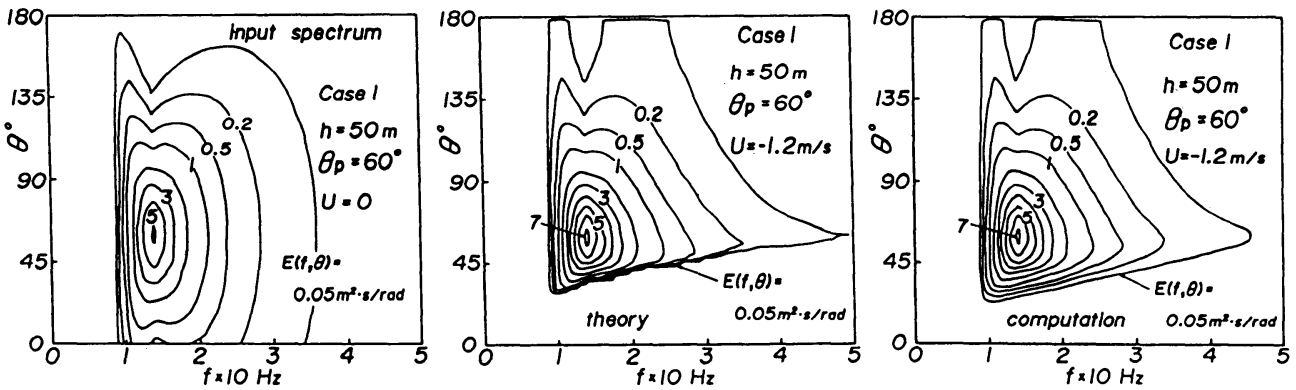

Fig. 8 Change of directional spectrum in case of uniform depth (case 1).
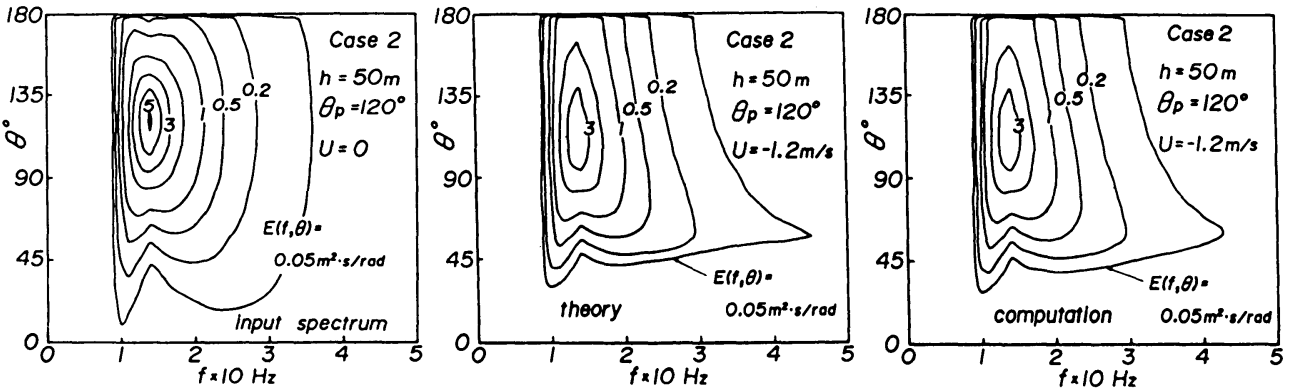

Fig. 9 Change of directional spectrum in case of uniform depth (case 2).

波の場合より一層大きく減少する．また，理論と計算結 果の対応は case 1 よりはるかによく, 両者はほぼ一致 している.

Fig. 7 は海底勾配 $i=1 / 50$ の平行等深線地形水域に $\theta_{p}=60^{\circ}$ あるいは $\theta_{p}=120^{\circ}$ の波浪が入射した場合 (case 3 および case 4) の計算結果であり, 最大水深が異なるけ れビも, Fig. 6 との比較から海底地形変化の影響を知る ことができる.さて, 逆流成分が卓越する case 3 の場合, 規則波については, 逆流による波高増大効果が中間水深 部における shoaling および屈折による波高減少効果に よって打ち消されるので，波高は減少するが，極浅水部 では波高増大項としての shoaling および流れの影響が 屈折による波高堿少効果に打ち勝って, 波高は増加傾向 を示す.また，不規則波の場合には Fig. 6 でみたように， 流れは波高減少効果をもつので, 水深変化に伴う波高減 少量が規則波の場合より大きく，逆に shoaling が卓越 する極浅水部では波高増大量は規則波の場合より小さ い. そして, この場合, 理論曲線と計算結果の相違は一 様水深の場合に比べて若干小さくなっている.

一方, 順流成分が卓越する case 4 の場合, 規則波, 不規則波のいずれについても，流れ，屈折および shoaling は中間水深部において波高减少効果をもつので, 波 高は水深減少に伴って減少するが, 境界端近くの浅水部 では shoaling の影響が顕著になり，波高が増大する. この波高変化の様子は, 浅水部で規則波の波高増加が不
規則波のそれより急激である点を除いて，相互によく似 ている. また, 理論結果と数値計算結果の対応は, わず かな隔たりがみられる極浅水部を除いて良好である.

次に, case 1 および case 2 に対応して, 入力方向ス ペクトルおよび $U=-1.2 \mathrm{~m} / \mathrm{s}$ 地点（境界端の隣の格子 点）における方向スペクトルの等值線を理論および数值 計算について図示したのがそれぞれ Fig. 8 および Fig. 9 である.まず, case 1 では逆流成分が卓越するので, $\theta_{\mathrm{cl}}<\theta<90^{\circ}$ の範囲の方向スペクトル值が増大するが, 前述のように $\theta<\theta_{c 1}$ では方向スペクトルの伝播が遮断 されるので, 理論結果では, 方向スペクトル值の急変部 が明瞭に形成されている. また, 高周波側ほど方向スペ クトルの存在する方向幅が狭くなることに対応して, 等 值線幅は高周波側ほど減少している. 一方, 数値計算結 果もこれらの方向スペクトルの変化特性をよく再現して いるが, 方向スペクトルの急変部でエネルギーがもれる ため, 方向スペクトルの等值線分布は全体としてやや平 滑化されている. なお, 方向スペクトルの主方向は $\theta_{\boldsymbol{p}}=60^{\circ}$ より若干小さくなる.

ついで, case 2 では順流成分が卓越するので， $\theta>90^{\circ}$ の範囲の方向スペクトル值は減少し, 一方, $\theta_{c 1}<\theta<$ $90^{\circ}$ では方向スペクトル值が増大するものの, その絶対 值は相対的に小さいので, 方向スペクトルの最大值を示 す等值線は平坦になる. そして, この場合も, 方向スペ クトルの主方向は $\theta_{p}=120^{\circ}$ より若干減少する. 
Fig. 10 および Fig. 11 は, case 3 および case 4 に対応する $U=-1.2 \mathrm{~m} / \mathrm{s}$ 地点での方 向スペクトルの等值線を理論および数値計算 について示したものであり, この場合, 入力 方向スペクトルはそれぞれ Fig. 8 および Fig. 9 と同一であるので, 省略されている. まず, Fig. 8 と Fig. 10 を比べると, case 3 では, 水深変化に伴う屈折の影響により波向 は $\theta=90^{\circ}$ に向かって集中する傾向をもつ結 果, 低周波側では方向スペクトルの存在する 限界波向, $\theta_{c 1}$ の值も増加するので, 方向ス ペクトルが有意な值をとる方向幅が減少し, 理論, 数値計算いずれの等值線分布にも方向 スペクトルの集中傾向が顕著に現われてい る. また, 流れによる波向の減少効果より屈 折による波向の増大効果が卓越するので, 主 方向は入力として与えた $\theta_{p}=60^{\circ}$ より大きく なる. 一方, Fig. 9 と Fig. 11 を比べると, 順流成分の卓越する case 4 では, 流れによ るエネルギー減少効果を受けるものの, 屈折 効果により波浪成分が主方向に集中するとと もに, shoalingによりエネルギーが増大す るので, 方向分布幅が Fig. 9 よりかなり狭く なっている. なお, 水深変化と流れが共存する場合, 工 ネルギーの伝播が遮断される限界波向は $\theta>90^{\circ}$ の範囲 に存在するので, 特に順流成分が卓越する case 4 の場 合にも方向スペクトル値の急変部が形成されるが, 前述 のように数値計算ではこれらがやや平滑化されている.

\section{4. 結語}

以上, 本研究では, エネルギー逸散が無視される場合 に任意の流速分布および海底地形変化による波浪変形の 数値計算法を規則波および不規則波について提案すると ともに, それぞれ単純な条件下における理論と計算結果 との比較から数値モデルの妥当性を確認した.

まず，規則波の場合には，波数成分および wave action の変化を記述する方程式が同じ特性曲線をもつこ とに注目して, 第 1 段階では特性曲線法と一次平面補間 式の併用により格子点における波向および波数を求め, 第 2 段階では同様の方法により格子点上での波高を算出 する数値計算法を開発した. そして, 岩垣ら（1977）が 取り扱った一様水深および一様勾配地形に一次元流れが 存在する場合に対して数値計算結果はほぼ完全に理論結 果と一致することを確かめた.

次に，不規則波の場合には，各周波数および方向に対 して別個に定義される波向線上で成立する wave action 波数スペクトル密度の保存則を特性曲線法の 1 つである

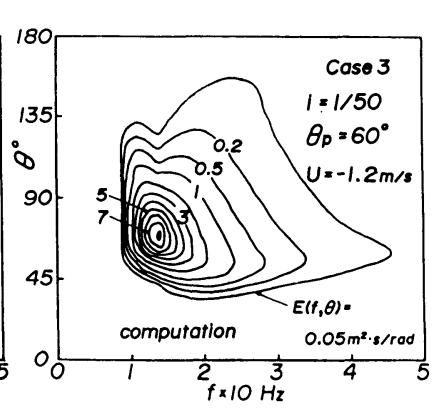

Fig. 10 Change of directional spectrum in case of sloping beach (case 3 ).
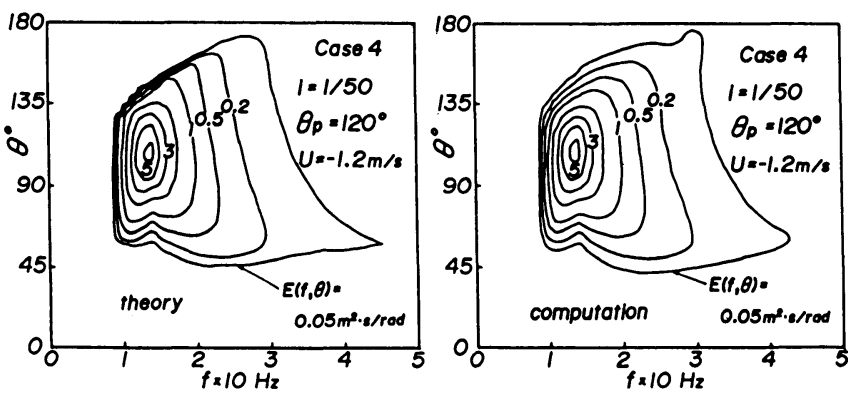

Fig. 11 Change of directional spectrum in case of sloping beach (case 4 ).

piecewise ray method と高次平面補間式および方向に 関する一次補間式を組み合わせた方法により方向スペク トルの時空間変化を計算する数值計算法を開発した．そ して, 一様水深や一様勾配地形上に一次元流れが存在す るという単純な場合に対して波浪変形計算を行い，理論 結果と計算結果とを比較・検討した. その結果, それぞ れ逆流成分および順流成分が卓越するいずれの場合にも 波高は入射波高より減少し，特に逆流成分が卓越する場 合の波浪の変形特性は規則波の場合と大きく相違するこ とや，逆流成分が卓越する場合には，方向スペクトルの 分布形状が尖鋭化し, 逆に順流成分が卓越する場合には, 方向スペクトルが平坦化することおよび水深減少は方向 スペクトルの分布形状を尖鋭化するので，水梁減少域が 存在すればいずれの場合にも方向スペクトルの分布形状 がより鋭くなることが理論および数值計算結果の両者か ら明らかにされた．また，理論によれば，対象地点に方 向スペクトルが到達する限界の波向が存在し, その近傍 では方向スペクトルが急激に変化するのに対し, 数值計 算では方向に関するエネルギーのもれのため平滑化が行 われる結果, 波高の数值計算結果は特に逆流成分が卓越 する場合に理論値よりやや大きくなることが示された.

しかし，この平滑化は波高や方向スペクトルの変化特性 の特徵を損なうものでないので, 本研究の数値計算法は 十分有用であると考えられる. 
最後に, 多くの文献を心よく提供された京都大学工学 部 酒井哲郎助教授ならびに数值計算や図の作成に助力 願った愛媛大学工学部海洋工学科 大福 学技官に感謝 するとともに, 本研究は文部省科学研究費による研究成 果の一部であることを付記する. かお，数値計算は愛媛 大学情報処理センターのFACOM M-180 II AD および 九州大学大型計算機センターの FACOM M-382 によっ た。

\section{参考文献}

1) Skovgaard, O. and Jonsson, I. G. : Currert depth refraction using finite elements, Proc. of 15th Conf. on Coastal Eng., pp. 721 737, 1976.

2）岩垣雄一・酒井哲郎・岡 幸雄: 流れによる波の屈折と 波高変化, 第 24 回海岸工学講演会論文集, pp. $25 \sim 29$, 1977.

3）山田 正・渡辺一浩・小森宏: 非線型性を考慮した水 面波の屈折に関する研究, 土木学会論文報告集,第 342 号, pp. 143 152, 1984.

4) Wang, H. and Yang, W. C. : Wave spectral transformation measurement at Sylt, North Sea, Coastal Eng. , 5, pp. 1 34, 1981.

5）酒井哲郎・小関仁彦・岩垣雄一：流れによる不規則波の 屈折の数値計算, 第 28 回海岸工学講演会論文集, pp. 118 122, 1981.

6) Chen, Y.H. and Wang, H. : Numerical model for nonstationary shallow water wave spectral transformation, Jour. of Geophy. Res., Vol. 88, No. C14, pp. 9851 9863, 1983.

7) Willebrand, J. : Energy transport in a nonlinear and inhomogeneous random gravity wave field, Jour. of Fluid Mech., Vol. 70, Part 1, pp. 113 126, 1975.

8) James, E.C., Collins, J.I., Wanger, P.A. and Tayfun, M. A. : Ocean wave spectrum modifications by spatially varying currents and bottom topography, Tetra Tech., Rep. TC-493-1, 1977.

9) LeBlond, P.H. and Mysak, L. A. : Waves in the Ocean, Elsevier Scientific Publ. Co., pp. 323 324, 1978.

10) Tayfun, M.A., Dalrymple, R.A. and Yang, C. Y. : Random wave-current interactions in water of varying depth, Ocean Eng., Vol.3, pp.403 420, 1976.

11) Mathiesen, M. : Current-depth refraction of directional wave spectra, Sympo. on Description and Modelling of Directional Seas, C-6-1 C-6-8, 1984.

12) Brink-Kjaer : Depth-current refraction of wave spectra, Sympo. on Description and Modelling of Directional Seas, C-7-1 C-7-12, 1984.

(1984. 7. 18 • 受付) 